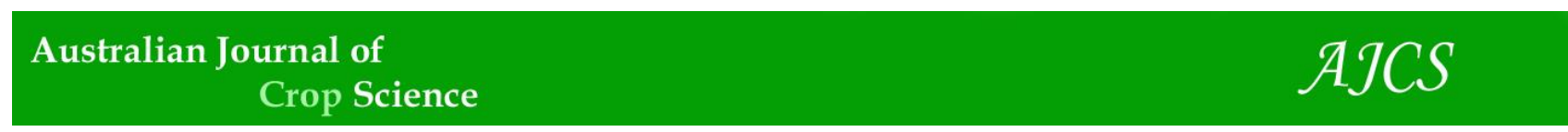

AJCS 11(11):1399-1405 (2017)

ISSN:1835-2707

doi: 10.21475/ajcs.17.11.11.pne475

\title{
Improving the sustainability of tobacco cultivation by optimizing nitrogen fertilization
}

\author{
Sifola Maria Isabella*, Raimondi Giampaolo, Maggio Albino \\ Department of Agricultural Sciences, University of Napoli Federico II, Via Università 100, 80055 Portici (Napoli), \\ Italy
}

*Corresponding author: sifola@unina.it

\begin{abstract}
Tobacco covers over 4.3 million hectares of agricultural lands in the world and, as other crops, must be grown following sustainability principles. Tobacco Burley type is fertilized worldwide with rates of nitrogen that can be reduced without significant impact on product yield and quality. In this experiment, Burley tobacco (Nicotiana tabacum L.) plants were grown in the field with or without irrigation and fertilized with $0,120,240$ or $360 \mathrm{~kg} \mathrm{~N}^{-1}$ over two growing seasons. The experimental design was a splitplot, with irrigation treatments in the main plots and doses of $\mathrm{N}$ in the sub-plots, with three replications. The elemental plot area was $100 \mathrm{~m}^{2}(10 \times 10 \mathrm{~m})$ in both years. The objective was to address $\mathrm{N}$ needs based on critical concentrations of $\mathrm{N}\left(\mathrm{N}_{\mathrm{ct}}\right)$ and Nitrogen Nutrition Index (NNI), both of which are not available for this crop. Plant dry matter and leaf area were measured during the crop cycle. Specific leaf weight, total N, $\mathrm{N}_{\mathrm{ct}}$ and NNI were determined. $\mathrm{N}_{\mathrm{ct}}$ ranged between 2.2 and $4.0 \%$ in 2 years. NNI was greater under non-irrigated than irrigated conditions in both years and they generally increased significantly with $\mathrm{N}$ fertilization up to $240 \mathrm{~kg}$ $\mathrm{N} \mathrm{ha}^{-1}$. NNI measured during the rapid growth was positively correlated with yield under irrigated conditions $\left(\mathrm{r}=0.656^{*}\right)$. Based on our results, when water is not limiting, the NNI measured at early growth stages could give a useful indication of the effectiveness of fertilization, i.e. the higher the NNI will be in this phase the better will be the response in terms of cured leaves production.
\end{abstract}

Keywords: Critical N concentration, Nitrogen Nutrition Index, Irrigation, Mediterranean climate.

Abbreviations: DAT_days after transplanting; DM_dry matter; ET _ccrop evapotranspiration; I_fully-irrigated; LA_leaf area; LSD_ least significant difference; $\mathrm{N}_{\mathrm{ct} \_}$critical N concentration; NI_non-irrigated; NNI_nitrogen nutrition index; $\mathrm{N}_{\mathrm{t} \_}$total nitrogen; Y, year .

\section{Introduction}

Water and nitrogen availability are two critical determinants of agricultural productions affecting both yield and product quality. Morover, environmental aspects associated to water and nitrogen use in agriculture are becoming increasingly relevant since water availability for irrigation purposes is declining as a consequence of climate change (Parida and Suja, 2015; Papadopoulou et al., 2016), intensive farming and the irrigation practice per se, which is causing soil and water salinization in many areas of the world (De Pascale et al., 2012). Excessive nitrogen fertilization has also deleterious consequences on the environment and human health through contamination of the groundwater and accumulation of nitrates in plant tissues beyond safety levels (Komatsuzaki and Ohta, 2007; Kaiser et al., 2015). The need for proper water and nitrogen management for food and nonfood crops is therefore a focal point of sustainable agricultural systems.

Soil and plant based techniques have been developed to assess optimal/sustainable $\mathrm{N}$ fertilization regimens in response to water availability. Soil-based techniques, however, are not suited for Mediterranean areas. In these environments, seasonal variability of both soil moisture and temperature is a serious constraint for accurate forecast of the actual amounts of mineral $\mathrm{N}$ available to plants since mineralization rates are greatly affected by these two parameters (Pessarakli, 1994; Zhang et al., 2015). Among plant-based approaches, the critical $\mathrm{N}$ concentration $\left(\mathrm{N}_{\mathrm{ct}}\right.$ expressed as \% of Dry Matter, DM) has been proven to be a reliable parameter for monitoring $\mathrm{N}$ fertilization rates in the soil-plant system (Lemaire et al., 2007). $\mathrm{N}_{\mathrm{ct}}$ represents the minimum concentration of $\mathrm{N}$ in the above-ground biomass that is required to produce the maximum biomass accumulation at a given time. It has originally been proposed to optimize $\mathrm{N}$ fertilization in wheat (Justes et al., 1994) and later tested in other crops (Sheehya et al., 1998; Plenet and Lemaire, 2000; Colnenne et al., 2002; Lemaire et al., 2007; Agnusdei et al., 2010; Oliveira et al., 2013; Zhao, 2014). A few studies have demonstrated that the concentration of $\mathrm{N}$ in plant tissues is time dependent and it decreases over plant growth (Hirose and Werger, 1987; Marino et al., 2004; Taub and Whang, 2008). This decrease has been attributed to the so-called dilution effect, which is due to changes in allometric relationships between $\mathrm{N}$ concentrations and shoot dry matter due to leaves senescence processes and/or $\mathrm{N}$ remobilization toward grains, fruits or roots (Plenet and Lemaire, 2000; Lemaire et al., 2007). For field crops, the following relationship between $\mathrm{N}$ concentration and aboveground biomass describes such dilution effect, otherwise defined by the $\mathrm{N}$ critical dilution curve:

$N=a D M^{-n}$

where DM is the crop dry matter, $\mathrm{N}$ is the total nitrogen as \% DM, $a$ and $n$ are positive crop-specific constants. In practice, $a$ is the shoot $\mathrm{N}$ when $\mathrm{DM}$ is $1 \mathrm{Mg} \mathrm{ha}^{-1}$, whereas $n$ is the ratio between the relative accumulation rates of $\mathrm{N}$ and DM. A value of $n$ less than 1 implies a decrease of the rate of $\mathrm{N}$ uptake per unit of dry weight accumulated $(\mathrm{dN} / \mathrm{dW})$ with 
increasing crop biomass (W), which determines a decrease in plant $\mathrm{N}$ concentration (Reyes et al., 2015). N critical dilution curves can be used for practical applications (Lemaire et al., 2007; Divito et al., 2016; Zhao et al., 2016) such as the definition of the Nitrogen Nutrition Index (NNI):

$N N I=N_{t} / N_{c t}$

Where; $\mathrm{N}_{\mathrm{t}}$ is the total $\mathrm{N}$ concentration of the aerial biomass of plants and $\mathrm{N}_{\mathrm{ct}}$ is the critical concentration of $\mathrm{N}$ for the same biomass. If NNI is equal to or greater than $1, \mathrm{~N}$ is not limiting for plants but if it is less than $1, \mathrm{~N}$ is considered to be limiting and it can be increased to maximize yield.

Despite the health consequences of tobacco use, tobacco is grown over 4.3 million hectares of agricultural lands in the world and it still represents an important source of income for many small-medium farms (FAOSTAT, 2014). Adopting sustainability principles in tobacco cultivation is therefore mandatory to reduce the environmental impact of its cultivation. In Southern Italy, levels of nitrogen fertilization for optimal Burley tobacco yield have been found to be between 120 and $240 \mathrm{~kg} \mathrm{ha}^{-1}$ under irrigated conditions. Nitrogen fertilization at 120 and $240 \mathrm{~kg} \mathrm{ha}^{-1}$ also produced good results in terms of leaf burning capacity, filling power and tar concentration in the smoke. However, physiologic and specific field dynamics of these responses are unknown. Therefore, there are reasonable margins for improving Nitrogen Use Efficiency in Mediterranean environments (Sifola and Postiglione, 2003). In this study, we systematically assessed $\mathrm{N}$ needs in tobacco Burley for which critical concentrations of $\mathrm{N}$ and $\mathrm{NNI}$ are not available.

\section{Results and Discussion}

\section{Irrigation and $N$ fertilization affect yield and yield components of Burley tobacco.}

The number of leaves per plant was significantly affected by the year. In particular, it was greater in Year II compared to Year I (Table 1). In contrast, no effect of the growing season was determined on both yield and mean leaf weight (Table 1). The total yield increased with $\mathrm{N}$ fertilization up to $360 \mathrm{~kg}$ $\mathrm{N} \mathrm{ha}^{-1}$ and it increased more under irrigated than non-irrigated conditions (significant $\mathrm{I} \times \mathrm{N}$ interaction; Fig. 1A). The number of leaves per plant also significantly increased up to 120 and $240 \mathrm{~kg} \mathrm{~N} \mathrm{ha}^{-1}$, with no further increase at higher $\mathrm{N}$ doses (Table 1). There was no significant I x N interaction for this parameter. In contrast, the interaction $\mathrm{I} \times \mathrm{N}$ was significant for the cured leaves weight, with higher leaf weight at increasing $\mathrm{N}$ fertilization only under irrigation and no significant increase under water shortage (Fig. 1B). At harvest, irrigated plants accumulated more DM than nonirrigated ones in both years. It did not significantly vary at increasing $\mathrm{N}$ under non-irrigated conditions, whereas it increased at increasing $\mathrm{N}$, with irrigation, up to 360 and 240 $\mathrm{kg} \mathrm{N} \mathrm{ha}^{-1}$ in year I and II, respectively (data not shown). Nonirrigated plants reached the maximum leaf area (LA) two weeks before irrigated plants (data not shown). In both years, LA of fully-irrigated plants was greater compared to nonirrigated ones. However, LA increased significantly $(+191 \%$ and $+181 \%$ in Year I and II, respectively) at $240 \mathrm{~kg} \mathrm{~N}^{-1}$ under irrigated conditions, without any further increase at the highest fertilization rates (data not shown).

Assessing optimal levels of $\mathrm{N}$ fertilization is essential to maximize yield and quality parameters while preserving the environmental/economic consequences of $\mathrm{N}$ fertilizers overuse (Bashir et al., 2013). Crop system specificities however call for a detailed assessment of $\mathrm{N}$ requirements that cannot be generalized since they need to best respond to cultivar requirements, cultivation practices and/or new technology advancement (Basso et al., 2016). In contrast to previously reported results, obtained under comparable environmental and experimental conditions (Sifola and Postiglione, 2002, 2003), in the present experiment N fertilization significantly increased yield up to $360 \mathrm{~kg} \mathrm{~N}^{-1}$ (Table 1). Nevertheless, taking into account different yield components, optimal levels of nitrogen fertilization for Burley tobacco were between 120 and $240 \mathrm{~kg} \mathrm{~N} \mathrm{ha}^{-1}$, particularly under irrigated conditions (Table 1; Figure 1). The dynamic of nitrogen accumulation and redistribution is of particular relevance in tobacco since it could greatly affect quality/health aspects of the final product. Nitric-N in plant tissues generally increases with increasing $\mathrm{N}$ fertilization in different species and is affected by water availability (Qiu et al., 2014; Bashir et al., 2013). Considering that excess of nitrogen in tobacco tissues can react with alkaloids to form specific $\mathrm{N}$-nitrosamines, one of the deleterious compounds identified in tobacco products, these data suggest that there is still a useful range of action (between 120 and $240 \mathrm{~kg} \mathrm{~N} \mathrm{ha}^{-1}$ ) to improve $\mathrm{N}$ fertilization so to reduce harmful effects of smoking. In tobacco, $\mathrm{N}$ content of younger leaves normally increases during the senescence of older/basal leaves since nitric-N could be re-mobilized within plant parts towards active sinks (Masclaux et al., 2000; Xi et al., 2008). However, later in the growing season, roots also become an important sink for $\mathrm{N}$, which is required for nicotine synthesis (Hildreth et al., 2011; Pakdeechanuan et al., 2012; Xi et al., 2008). Therefore, $\mathrm{N}$ distribution within the plant is tightly linked, and mostly driven, by developmental processes. Our results show that the percentage of nitrate-N, calculated on the total $\mathrm{N}$ accumulated by plants at the end of the growing period, increased with increasing $\mathrm{N}$ fertilization up to $120-240 \mathrm{~kg} \mathrm{~N}$ $\mathrm{ha}^{-1}$ under stressed conditions and up to $360 \mathrm{~kg} \mathrm{~N}^{-1}$ under irrigated ones (data not shown). Consistent with our results, Borges et al. (2012) also reported optimal fertilization levels around $140-190 \mathrm{~kg} \mathrm{~N} \mathrm{ha}^{-1}$ for Cuban cigar tobacco, which further highlights the site-specific requirements for optimal $\mathrm{N}$ fertilization. In our conditions, DM accumulation, LA expansion and weight of cured leaves did not improve at $\mathrm{N}$ rates above $240 \mathrm{~kg} \mathrm{ha}^{-1}$.

\section{N dilution curve and NNI of tobacco}

Under our experimental conditions, a specific tobacco $\mathrm{N}$ dilution curve was found (Fig. 2A), which well described the $\mathrm{N}$ dilution process from the beginning of rapid growth (39 and 35 DAT in year I and II , respectively) to full bloom or commercial harvest, which occurred at 67 and 101 DAT in the first and second year, respectively (Fig. 2A). The $\mathrm{N}_{\mathrm{ct}}$ ranged between 2.2 and $4.0 \%$ over the 2 years and it was in line with crop dry matter variations (from 0.5 to $6.4 \mathrm{Mg} \mathrm{ha}^{-1}$ ) (Fig. 2A). The irrigation regime did not affect the relationship between plant accumulation of $\mathrm{N}$ and $\mathrm{DM}$ and the values of $\mathrm{N}_{\mathrm{ct}}$ (a single function was found for both nonirrigated and irrigated conditions, Fig. 2A). Overall, the model we used met $63 \%$ of the variability (Fig. 2A). In both years, NNI was greater under stressed than irrigated conditions and it generally increased significantly with $\mathrm{N}$ fertilization up to $240 \mathrm{~kg} \mathrm{~N} \mathrm{ha}^{-1}$, without any further increase 
Table 1. The effect of year, irrigation and $\mathrm{N}$ fertilization treatments on yield and yield components of Burley tobacco.

\begin{tabular}{|c|c|c|c|}
\hline & $\begin{array}{l}\text { Yield of cured leaves } \\
\left(\mathrm{Mg} \mathrm{ha}^{-1}\right)\end{array}$ & $\begin{array}{c}\text { Cured leaves } \\
\text { (no plant }^{-1} \text { ) }\end{array}$ & $\begin{array}{l}\text { Cured leaves mean weight } \\
(\mathrm{g})\end{array}$ \\
\hline \multicolumn{4}{|l|}{ Year (Y) } \\
\hline I & $1.21 \mathrm{a}$ & $13.4 \mathrm{~B}$ & $5.14 \mathrm{a}$ \\
\hline II & $1.42 \mathrm{a}$ & $15.5 \mathrm{~A}$ & $4.85 \mathrm{a}$ \\
\hline \multicolumn{4}{|c|}{ Irrigation (I) } \\
\hline NI & $1.05 \mathrm{~B}$ & $13.9 \mathrm{a}$ & $4.20 \mathrm{~B}$ \\
\hline I & $1.58 \mathrm{~A}$ & $15.0 \mathrm{a}$ & $5.80 \mathrm{~A}$ \\
\hline \multicolumn{4}{|c|}{$\mathrm{N}$ fertilization $(\mathrm{N})$} \\
\hline 0 & $0.85 \mathrm{D}$ & $12.7 \mathrm{~B}$ & $3.91 \mathrm{C}$ \\
\hline 120 & $1.29 \mathrm{C}$ & $14.5 \mathrm{~A}$ & $4.77 \mathrm{~B}$ \\
\hline 240 & $1.48 \mathrm{~B}$ & $15.4 \mathrm{~A}$ & $5.40 \mathrm{~A}$ \\
\hline 360 & $1.69 \mathrm{~A}$ & $15.2 \mathrm{~A}$ & $5.91 \mathrm{~A}$ \\
\hline \multicolumn{4}{|l|}{ ANOVA } \\
\hline $\mathrm{Y}$ & NS & $* *$ & NS \\
\hline I & $* *$ & NS & $* *$ \\
\hline Y x I & NS & NS & NS \\
\hline $\mathrm{N}$ & $* *$ & $* *$ & $* *$ \\
\hline $\mathrm{Y} \times \mathrm{N}$ & NS & NS & NS \\
\hline I x N & $*$ & NS & $*$ \\
\hline Y x I x N & NS & NS & NS \\
\hline
\end{tabular}

Analyses of variance (ANOVA) table reports significance of treatments and their interactions. Different letters indicate least significant differences at $\mathrm{P}<0.05 ; \mathrm{P}<0.01$ (capital letters); *significant at $\mathrm{P}<0.05 ; * *$ significant at $\mathrm{P}<0.01 ; \mathrm{NS}$, not significant. $\mathrm{NI}=$ non-irrigated; $\mathrm{I}=$ fully-irrigated; $0,120,240$ and $360 \mathrm{~kg} \mathrm{~N}$ ha ${ }^{-1}$.

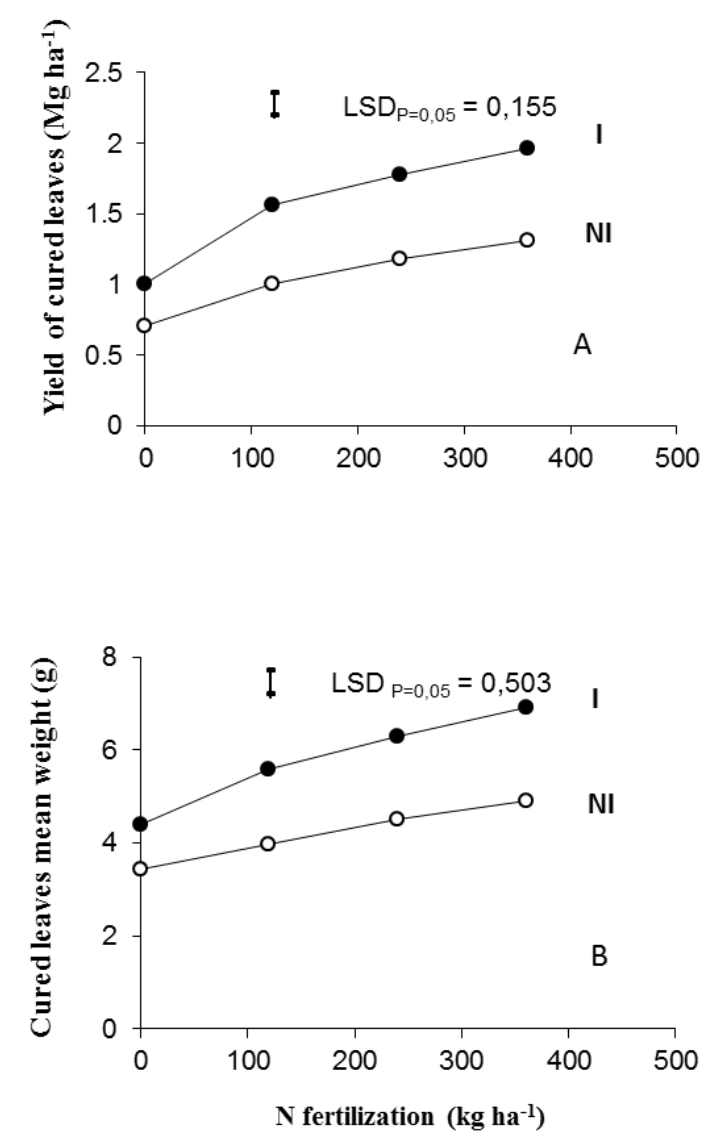

Fig 1. The effect of $\mathrm{N}$ fertilization treatments $\left(0,120,240\right.$ e $\left.360 \mathrm{~kg} \mathrm{ha}^{-1}\right)$ on yield of cured leaves (A) and cured leaves mean weight (B) of non-irrigated and fully-irrigated plants. Bars indicate least significant differences (LSD) of I x N interactions at $\mathrm{P} \leq 0.05$. NI, non-irrigated; I, fully-irrigated. 
Table 2. The effect of irrigation and N fertilization treatments on Nitrogen Nutrition Index (NNI) of Burley tobacco.

\begin{tabular}{llll}
\hline \multicolumn{3}{c}{ Year I } & \multicolumn{1}{l}{ Year II } \\
\hline DAT & 54 & 67 & 101 \\
\hline Irrigation (I) & & & \\
NI & 0.81 & $1.08 \mathrm{a}$ & $1.13 \mathrm{a}$ \\
$\mathrm{I}$ & 0.84 & $0.89 \mathrm{~b}$ & $0.82 \mathrm{~b}$ \\
& & & \\
$\mathrm{~N}$ fertilization (N) & & & \\
0 & $0.65 \mathrm{C}$ & $0.81 \mathrm{C}$ & $0.76 \mathrm{C}$ \\
120 & $0.80 \mathrm{~B}$ & $0.95 \mathrm{~B}$ & $0.93 \mathrm{~B}$ \\
240 & $0.90 \mathrm{~A}$ & $1.09 \mathrm{~A}$ & $1.08 \mathrm{~A}$ \\
360 & $0.95 \mathrm{~A}$ & $1.09 \mathrm{~A}$ & $1.13 \mathrm{~A}$ \\
\hline ANOVA & & & \\
\hline $\mathrm{I}$ & $\mathrm{NS}$ & $*$ & $*$ \\
$\mathrm{~N}$ & $* *$ & $* *$ & $\mathrm{NS}$ \\
$\mathrm{Ix} \mathrm{N}$ & $\mathrm{NS}$ & $\mathrm{NS}$ & \\
\hline
\end{tabular}

Analyses of variance (ANOVA) table reports significance of treatments and their interactions. Different letters indicate least significant differences at $\mathrm{P}<0.05$; $\mathrm{P}<0.01$ (capital letters); *significant at $\mathrm{P}<0.05 ; * *$ significant at $\mathrm{P}<0.01$; NS, not significant. NI = non-irrigated; $\mathrm{I}=$ fully-irrigated; $0,120,240$ and $360 \mathrm{~kg} \mathrm{~N}$ ha ${ }^{-1}$; DAT, days after transplanting.
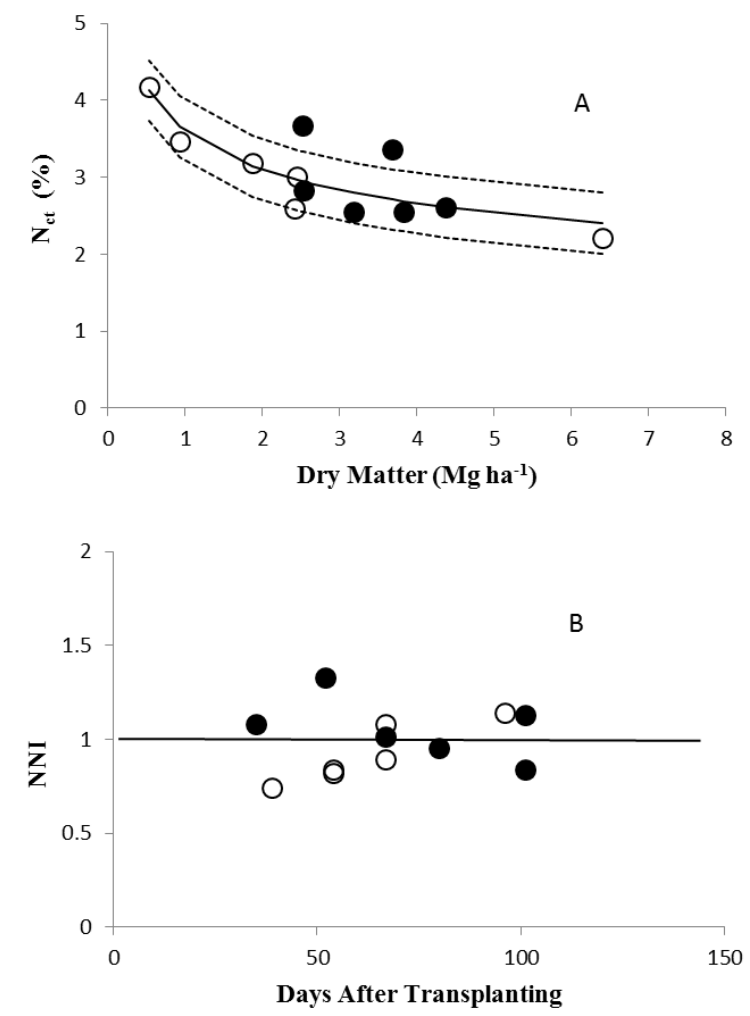

Fig 2. Critical N dilution curve (A) and nitrogen nutrition index (NNI, B) of tobacco in Year I (o) and Year II (•). Points in (A) are $\mathrm{N}_{\mathrm{ct}}$ calculated. Equation in (A): $\mathrm{y}=3.604 \mathrm{x}^{-0.218}, \mathrm{R}^{2}=0.634 * *$. Dotted lines in (A) indicated the confidential interval curves at $95 \%$.

Table 3. Physical and chemical properties of soils (means over $0-0.6 \mathrm{~m}$ soil layer) in the two years.

\begin{tabular}{lcc}
\hline & Year I & Year II \\
\hline Sand (\%) & 47.0 & 44.3 \\
Silt (\%) & 20.8 & 23.7 \\
Clay (\%) & 32.2 & 32.0 \\
pH & 6.9 & 7.0 \\
Organic matter (\%) & 1.325 & 1.438 \\
N (Kjeldahl) (\%) & 0.107 & 0.121 \\
Field Capacity (0.03 MPa, \% dry weight) & 22.7 & 26.8 \\
Wilting Point (1.5 MPa, \% dry weight) & 14.7 & 16.0 \\
\hline
\end{tabular}


at the highest $\mathrm{N}$ fertilization dose (Table 2). Overall, regardless of the imposed treatments (irrigation and $\mathrm{N}$ fertilization), NNI was greater than 1 (indicative of overfertilization) in the first part of the growing season (active growth) of Year II (Fig. 2B) whereas the opposite response (under-fertilization) was found in Year I during the same period (Fig. 2B).

The critical nitrogen concentration of a plant can be defined as the minimum nitrogen concentration required for maximum growth rate at any time. As previously reported, the $\mathrm{N}$ dilution effect strongly depends on changes in allometric relationships due to leaves senescence processes and/or $\mathrm{N}$ re-mobilization toward grains, fruits or roots (Lemaire et al., 2007). The $\mathrm{N}$ dilution curve calculated in the present experiment well described the dilution effect of $\mathrm{N}$ with plant growth (Fig 2A). In particular, the dilution effect in tobacco appeared mainly driven by $\mathrm{N}$ uptake (Recovery Fraction, RF; Sifola and Postiglione, 2003), which in the present experiment appeared to be positively affected by irrigation $(+79 \%)$ but negatively affected by $\mathrm{N}$ doses $(-43 \%)$ up to $360 \mathrm{~kg} \mathrm{ha}^{-1}$ (data not shown) and crop growth (Sifola and Postiglione, 2003; Lemaire et al., 2007). However, the dilution effect was only indirectly influenced by irrigation and $\mathrm{N}$ fertilization treatments as indicated by the single curve we found which well fitted all experimental conditions (Figure 2A). Our data also indicated that the critical dilution curve did not appear to be affected by climatic conditions (similar response in year I and II; Figure 2), which substantiates the reliability of this parameter for optimal $\mathrm{N}$ fertilization estimates. With respect to the stability of such dilution curves in different pedo-climatic conditions, these observations are consistent with those reported for other species (Justes et al., 1994; Sheehya et al., 1998). In both years, NNI was greater under stressed than irrigated conditions and generally increased significantly with $\mathrm{N}$ fertilization up to $240 \mathrm{~kg} \mathrm{~N} \mathrm{ha}^{-1}$, without any further increase at the highest $\mathrm{N}$ fertilization dose (Table 2).

\section{Matching nitrate fertilization with crop requirements}

Overall, independently of both irrigation and $\mathrm{N}$ fertilization rates, NNI was greater than 1 (indicative of over-fertilization) in the first part of the growing season (active growth) of Year II (Figure 2B) whereas the opposite response (underfertilization) was found in Year I during the same period (Figure 2B). In our experimental conditions the NNI index was positively influenced by $\mathrm{N}$ doses, reaching values slightly higher than 1 at 240 and $360 \mathrm{~kg} \mathrm{~N} \mathrm{ha}^{-1}$ (Table 2). These results indicate that in those conditions there was an excess of $\mathrm{N}$, possibly stored as inorganic (nitrate) or organic compounds in plant tissues (Marino et al., 2004), ready to be re-mobilized if needed (e.g. when the growth rates are still high). Similar responses were reported for annual ryegrass (Marino et al., 2004), potato (Hu et al., 2014) and wheat (Demotes-Mainard and Jeuffroy, 2001). N fertilization appeared limiting in the first part of the cropping cycle characterized by active growth and high $\mathrm{N}$ uptake rates (Sifola and Postiglione, 2003) in year I while the opposite pattern was observed in year II, indicative of overfertilization and luxury consumption. Considering that the crop maximum growth rate is achieved when NNI values are greater than or equal to 1 (Lemaire et al., 2007), our results demonstrate that when water was limiting the maximum growth was reached very early in the growing season (NNI was, on average, greater than 1 at 67 DAT). Consequently, any further $\mathrm{N}$ fertilization after 67 DAT would dramatically reduce NUE under those specific conditions. Moreover, NNI was always higher in non-irrigated than irrigated plants because senescence processes and/or $\mathrm{N}$ remobilization were likely very low under stressed conditions, particularly when the growth rate approached to 0 (Marino et al., 2004). As average of both $\mathrm{N}$ and irrigation treatments, NNI was always negatively related to $\mathrm{RF}$, as already reported for potato $(\mathrm{Hu}$ et al., 2014) and linseed (Dordas, 2011). Importantly, when measured during the rapid growth phase (54 DAT in year I), the NNI was positively and significantly correlated to yield under irrigated conditions $\left(\mathrm{r}=0.656^{*}\right.$; data not shown). This means that when water is not limiting the NNI, measured at early growth stages, could give a useful indication of the effectiveness of fertilization, i.e. the higher the NNI will be in this phase the better will be the response in terms of cured leaves production.

\section{Materials and methods}

\section{Plant material and treatments}

A Burley tobacco crop cv. C104 was grown over two consecutive years at the experimental farm "Torre Lama" of the University of Napoli Federico II (Southern Italy, $40^{\circ} 37$ 'N, $14^{\circ} 58^{\prime} \mathrm{E}$ ) on a clay-loam soil whose characteristics are reported in Table 3.

Seedlings were transplanted on 15 and 17 May in the first and second year, plant were grown until harvest as described in Sifola and Postiglione $(2002 ; 2003)$ and harvested in both years from the central part of each plot about 30 days after topping. Two irrigation treatments (non-irrigated control, NI, and fully-irrigated treatment, I) and 4 rates of $\mathrm{N}$ fertilization (non-fertilized control, 0, and fertilization with 120, 240 and $360 \mathrm{~kg} \mathrm{~N} \mathrm{ha}^{-1}$ ) were compared. The fully-irrigated treatment received an amount of water equal to $\mathrm{ET}_{\mathrm{c}}$ estimated from Class A pan evaporation rate measured on site. Plants were furrow irrigated when the soil water depletion exceeded $40 \%$ of the available water in the $0-0.15 \mathrm{~m}$ soil profile at transplanting and $0-0.5 \mathrm{~m}$ at maximum plant development. Overall, plants received seasonal volumes of 393 and 253 $\mathrm{mm}$ in the first and second year, respectively. In both years, NI plants received only $30 \mathrm{~mm}$ of water at transplanting. During the two years, air temperatures were in line with optimal crop growth requirements. In the first year, maximum daily values exceeded $30^{\circ} \mathrm{C}$ late in June and July and early in August and minimum temperatures ranged between 13 and $22^{\circ} \mathrm{C}$. In the second year, maximum temperatures exceeded $30^{\circ} \mathrm{C}$ only in the first ten days of June and August, while minimum temperatures ranged between 14 and $21^{\circ} \mathrm{C}$. Rainfall during the growing season was $23 \mathrm{~mm}$ in the first year, mostly concentrated in May. In the second year, rainfall was high at the end of May, June and July for a total of $183 \mathrm{~mm}$.

\section{Dry matter, leaf area, leaf curing and yield}

One plant per plot was harvested at 2-week intervals starting from the rosette stage (39 and 35 DAT in the first and the second year, respectively) up to the final harvest (95 and 101 DAT in the first and the second year, respectively). Leaves and stem were separately weighted and dried at $60^{\circ} \mathrm{C}$ to constant weight. The leaf area (LA, dm ${ }^{2}$ plant $\left.{ }^{-1}\right)$ was calculated on the leaf dry matter (leaf DM, g plant ${ }^{-1}$ ) based on the following linear regression as determined for tobacco in previous experiments (unpublished data):

$L A=173.02$ leaf $D M$ 
At commercial harvest, plants were air-cured by desiccation in ventilated rooms for about 45 days. Yield was assessed at standard leaf moisture content of $19 \%$ by counting the number of cured leaves per plant and their mean weight.

\section{$N$ analyses and $N$ critical dilution curve $\left(N_{c t}\right)$}

Total $\mathrm{N}$ concentration $\left(\mathrm{N}_{\mathrm{t}}\right)$ was calculated by summing the Kjeldahl-N and $\mathrm{NO}_{3}-\mathrm{N}$ as previously reported (Sifola and Postiglione, 2003). The critical points of $\mathrm{N}$ dilution curve $\left(\mathrm{N}_{\mathrm{ct}}\right)$ were determined following the procedure of Justes et al. (1994). Within each year, the above-ground DM $\left(\mathrm{Mg} \mathrm{ha}^{-1}\right)$ from different fertilization treatments $(0,120,240$ and $360 \mathrm{~kg}$ $\mathrm{N} \mathrm{ha}^{-1}$ ), at each sampling date and water regime, were subjected to analysis of variance (ANOVA) and means were separated by the Least Significant Difference (LSD) test at the probability level of 5\%. Only cases that met one of the following inequalities on statistical basis were chosen for further analysis:

$D M_{N 0}<D M_{N 120} \leq D M_{N 240}=D M_{N 360}$

$D M_{N 0}<D M_{N 120}<D M_{N 240} \leq D M_{N 360}$

where subscripts indicate $\mathrm{N}$ treatments which determined that $\mathrm{DM}\left(\mathrm{Mg} \mathrm{ha}^{-1}\right)$. Then, the relationship between DM and its $\mathrm{N}$ concentration, within each irrigation treatment or sampling date, was analyzed using the following bilinear model:

$$
\left\{\begin{array}{r}
Y=(\alpha+\beta x) ;(x<n) \\
Y=\gamma ;(x \geq n)
\end{array}\right.
$$

where $\alpha$ and $\beta$ are respectively the intercept and the slope of the first growing linear function of the model, $\gamma$ is the ordinate value at the point of the slope change, which represents the maximum DM produced by plants at that $\mathrm{N}$ rate and stage of growth, and $\mathrm{n}$ is the value of the abscissa at the slope change, which represents the $\mathrm{N}_{\mathrm{ct}}(\% \mathrm{DM})$. NNI was then calculated based on the ratio between $\mathrm{N}_{t} / \mathrm{N}_{\mathrm{ct}}$ (Lemaire et al., 2007).

\section{Experimental design and statistical analysis}

The experimental design was a split-plot, with irrigation treatments as main plots and doses of $\mathrm{N}$ as sub-plots, with three replications. The elemental plot area was $100 \mathrm{~m}^{2}(10 \mathrm{x}$ $10 \mathrm{~m}$ ) in both years. Results of yield and yield components were subjected to ANOVA using MSTATC (MSTATC, 1991), based on a split-plot design combined over years and means separated by the LSD test. The NNI at 54/67 DAT and 101 DAT in the first and second year, respectively, was analysed by the same design within each date and year. Dry matter was subjected to ANOVA as previously reported.

\section{Conclusions}

Analysis of the agronomic and physiological efficiency of $\mathrm{N}$ fertilization in tobacco Burley grown in a Mediterranean environment allowed us to identify the most effective dose for $\mathrm{N}$ fertilization between 120 and $240 \mathrm{~kg} \mathrm{~N}^{-1}$. These results were confirmed by RF, which was particularly low at the highest $\mathrm{N}$ fertilization doses. A single dilution curve was found in all experimental and weather conditions, which makes this response function useful for different climatic environments.

\section{Acknowledgments}

This research was funded by EU Community Fund for Tobacco Research and Information - Commission Regulament (EEC) n. 2427/93.

\section{References}

Agnusdei MG, Assuero SG, Lattanzi FA, Marino MA (2010) Critical $\mathrm{N}$ concentration can vary with growth conditions in forage grasses: implications for plant $\mathrm{N}$ status assessment and $\mathrm{N}$ deficiency diagnosis. Nutr Cycl Agroecosyst 88: 215-230.

Bashir MT, Ali S, Ghauri M, Adris A, Harun R (2013) Impact of excessive nitrogen fertilizers on the environment and associated mitigation strategies. Asian J Microbiol, Biotech Env Sci. 15: 213-221.

Basso B, Dumont B, Cammarano D, Pezzuolo A, Marinello F, Sartori L (2016) Environmental and economic benefits of variable rate nitrogen fertilization in a nitrate vulnerable zone. Sci Total Environ 545/546: 227-235.

Borges A, Morejón R, Izquierdo A, Monzón L, Ortega E, Rodés R (2012) Nitrogen fertilization for optimizing the quality and yield of shade grown cuban cigar tobacco: required nitrogen amounts, application schedules, adequate leaf nitrogen levels, and early season diagnostic tests. Beitr Tabakforsch. 25: 336-349.

Colnenne C, Meynard JM, Roche R, Reau R (2002) Effects of nitrogen deficiencies on autumnal growth of oilseed rape. Eur J Agron. 17: 11-28.

Demotes-Mainard S, Jeuffroy MH (2001) Partitioning of dry matter and nitrogen to the spike throughout the spike growth period in wheat crops subjected to nitrogen deficiency. Field Crop Res. 70: 153-165.

De Pascale S, Orsini F, Caputo R, Palermo MA, Barbieri G, Maggio A (2012) Seasonal and multiannual effects of salinisation on tomato yield and fruit quality. Funct Plant Biol. 39: 689-698.

Divito GA, Echeverría HE, Andrade FH, Sadras VO (2016) Soybean shows an attenuated nitrogen dilution curve irrespective of maturity group and sowing date. Field Crop Res. 186: 1-9.

Dordas CA (2011) Nitrogen nutrition index and its relationship to $\mathrm{N}$ use efficiency in linseed. Eur J Agron. 34: 124-132.

FAOSTAT (2014) Food and Agricultural Organization Gateway.

Hildreth SB, Gehmana EA, Yangd H, Lua RH, Ca RK, Hariche KC, Yua S, Lind J, Sandoea JL, Okumotoa S, Murphyd AS, Jeleskoa JG (2011) Tobacco nicotine uptake permease (NUP1) affects alkaloid metabolism. Pnas 108: 18179-18184.

Hirose T, Werger MJA (1987) Nitrogen use efficiency in instantaneous and daily photosynthesis of leaves in the canopy of a Solidago altissima stand. Physiologia Plantarum 70: 215-222.

Hu DW, Sun ZP, Li TL, Yan HZ, Zhang H (2014) Nitrogen nutrition index and the relationship with $\mathrm{N}$ use efficiency, tuber yield, radiation use efficiency and leaf parameters in potatoes. J I P Biol. 13: 1008-1016.

Justes E, Mary B, Meynard JM, Machet, JM, Thelier-Huche L (1994) Determination of a critical nitrogen dilution curve for winter wheat crops. Ann Bot. 74: 397-407.

Kaiser DR, Sequinatto L, Reinert DJ, Reichert JM, Rheinheimer DS, Dalbianco L (2015) High nitrogen fertilization of tobacco crop in headwater watershed contaminates subsurface and well waters with nitrate. J Chem. Article ID 375092.

Komatsuzaki M, Ohta H (2007) Soil management practices for sustainable agro-ecosystems. Sustain Sci. 2: 103-120. 
Lemaire G, van Oosterom E, Sheehy J, Jeuffroy MH, Massignam A, Rossato L (2007) Is crop N demand more closely related to dry matter accumulation or leaf area expansion during vegetative growth? Field Crop Res. 100: 91-106.

Marino MA, Mazzanti A, Assuero SG, Gastal F, Echeverria HE, Andrade F (2004) Nitrogen dilution curves and nitrogen use efficiency during winter-spring growth of annual ryegrass. Agron J. 96: 601-607.

Masclaux C, Valadier MH, Brugiere N, Morot-Gaudry JF, Hirel B (2000) Characterization of the sink/source transition in tobacco (Nicotiana tabacum L.) shoots in relation to nitrogen management and leaf senescence. Planta 211: 510518.

MSTAC (1991) A microcomputer program for design management and analysis of agronomic research experiments. Michigan State University, East Lansing, MI, USA.

Oliveira ECA, de Castro Gava GJ, Trivelin PCO, Otto R, Franco HCJ (2013) Determining a critical nitrogen dilution curve for sugarcane. J Plant Nutr Soil Sci. 176: 712-723.

Pakdeechanuan P, Shoji T, Hashimoto T (2012) Root-to-shoot translocation of alkaloids is dominantly suppressed in Nicotiana alata. Plant Cell Physiol. 53: 1247-1254.

Papadopoulou MP, Charchousi D, Tsoukala VK, Giannakopoulos C, Petrakis M (2016) Water footprint assessment considering climate change effects on future agricultural production in Mediterranean region. Desalin Water Treat. 57 (5): 2232-2242.

Parida A, Suja G (2015) Sustaining and enhancing crop productivity in an era of climate change. Curr Sci India 109 (3): 462-473.

Pessarakli M. (Ed.) (1994) Handbook of plant and crop physiology. Marcel Dekker, Inc., New York.

Plenet D, Lemaire G (2000) Relationships between dynamics of nitrogen uptake and dry matter accumulation in maize crops. Determination of critical N concentration. Plant Soil 216: $65-82$.
Qiu W, Wang Z, Huang C, Chen B, Yang R (2014) Nitrate accumulation in leafy vegetables and its relationship with water. J Soil Sci Plant Nutr. 14: 761-768.

Reyes J, Schellberg J, Siebert S, Elsaesser M, Adam J, Ewert F (2015) Improved estimation of nitrogen uptake in grasslands using the nitrogen dilution curve. Agron Sust Dev. 35: 15611570.

Sheehya JE, Dionoraa MJA, Mitchell PL, Penga S, Cassmanc KG, Lemaire G, Williams RL (1998) Critical nitrogen concentrations: implications for high-yielding rice (Oryza sativa L.) cultivars in the tropics. Field Crop Res. 59: 31-41.

Sifola MI, Postiglione L (2002) The effect of increasing $\mathrm{NaCl}$ in irrigation water on growth, gas exchange and yield of tobacco Burley type. Field Crop Res. 74: 81-91.

Sifola MI, Postiglione L (2003) Nitrogen use efficiency of irrigated and non irrigated tobacco (Nicotiana tabacum L.). Plant Soil 252: 313-323.

Taub DR, Wang XZ (2008) Why are nitrogen concentrations in plant tissues lower under elevated $\mathrm{CO}_{2}$ ? A critical examination of the hypotheses. J Integr Plant Biol. 50: 13651374.

Xi X, Li C, Zhang F (2008) Tobacco plants can use nitrogen taken up before mechanical wounding to synthesize nicotine afterwards. Plant Signal Behav. 3: 87-90.

Zhang YJ, Guo SL, Zhao M, Du LL, Li RJ, Jiang JS, Wang R, Li NN (2015) Soil moisture influence on the interannual variation in temperature sensitivity of soil organic carbon mineralization in the Loess Plateau. Biogeosciences 12: $3655-3664$.

Zhao B (2014) Determining of a critical dilution curve for plant nitrogen concentration in winter barley. Field Crop Res.160: 64-72.

Zhao B, Liu Z, Ata-Ul-Karim ST, Xiao J, Liu Z, Qi A, Ning D, Nan J, Duan A (2016) Rapid and nondestructive estimation of the nitrogen nutrition index in winter barley using chlorophyll measurements. Field Crop Res. 185: 59-68. 